\title{
Copper-doped Hydroxyapatite for Removal of Arsenic(V) from Aqueous System
}

\author{
S. A. Jahan', M. Y. A. Mollah' ${ }^{2}$, S. Ahmed ${ }^{1}$, M. A. B. H. Susan ${ }^{3} *$ \\ ${ }^{1}$ Bangladesh Council of Scientific and Industrial Research (BCSIR), Dr. Qudrat-I-Khuda Road, \\ Dhaka-1205, Bangladesh \\ ${ }^{2}$ University Grants Commission of Bangladesh, 29/1 Agargaon, Sher-E-Bangla Nagar, Dhaka-1207, \\ Bangladesh \\ ${ }^{3}$ Department of Chemistry, University of Dhaka, Dhaka-1000, Bangladesh \\ Received 16 May 2017, accepted in final revised form 10 September 2017
}

\begin{abstract}
In this work, pure and copper-doped hydroxyapatite (various wt $\%$ of $\mathrm{Cu}$ ) were synthesized by wet chemical precipitation method using eggshells as source of calcium. The efficiency of the prepared materials for removal of $\operatorname{arsenic}(\mathrm{V})$ from aqueous system has been investigated. Pure and $\mathrm{Cu}$ (II)-doped HAP were calcined at different temperatures ranging from $100-600{ }^{\circ} \mathrm{C}$. The synthesized HAPs were characterized by Fourier Transform Infrared (FT-IR) spectroscopy, X-ray Diffraction (XRD), Scanning Electron Microscopy (SEM), Energy Dispersive X-ray Spectroscpic Analysis (EDS), particle size analysis based on dynamic light scattering measurements, and Brunauer-Emmett-Teller (BET) surface area analysis. FT-IR spectra and XRD patterns of synthesized HAPs confirmed the formation of single HAP phase. XRD patterns showed decrease in crystallite size for $\mathrm{Cu}$-HAP compared to pristine HAP. BET surface area of Cu-HAP calcined at $300{ }^{\circ} \mathrm{C}$ increased to $153.39 \mathrm{~m}^{2} \mathrm{~g}^{-1}$ from $66.80 \mathrm{~m}^{2} \mathrm{~g}^{-1}$ for pure HAP. Finally, the synthesized HAPs were applied to remove $\mathrm{As}(\mathrm{V})$ from aqueous system. As $(\mathrm{V})$ removal efficiency for $\mathrm{Cu}-\mathrm{HAP}$ was two-fold higher than that of pure HAP. Adsorption behaviors were analyzed for As(V) adsorption on thermally treated pure and $\mathrm{Cu}-\mathrm{HAP}$ using Langmuir, Freundlich, and Temkin adsorption isotherms. Finally, the prospect of $\mathrm{Cu}(\mathrm{II})$-doped HAP for treatment of waste water containing heavy metals has been discussed.
\end{abstract}

Keywords: Hydroxyapatite; Arsenic; Surface area; Adsorption isotherm.

(C) 2017 JSR Publications. ISSN: 2070-0237 (Print); 2070-0245 (Online). All rights reserved. doi: http://dx.doi.org/10.3329/jsr.v9i4.32606 J. Sci. Res. 9 (4), 383-402 (2017)

\section{Introduction}

Arsenic, classified as a group 1 human carcinogenic substance by the World Health Organization (WHO) [1], has been reported in significant concentration in ground water

\footnotetext{
*Corresponding author: $\underline{\text { susan@du.ac.bd }}$
} 
in Bangladesh, Chile, China, India and few other countries [2]. Based on WHO guidelines, arsenic concentrations in drinking water should be strictly limited to $10 \mu \mathrm{gL}^{-1}$ [3]. Chronic intake of inorganic arsenic as drinking water or else with concentrations above this limit, may cause arsenicosis [4]. Arsenic(V) is generally the most common arsenic species present in the well oxygenated surface water [5]. Anthropogenic activities like manufacture of paints, dyes, ceramics and glass, electronics, pigments, antifouling agents, and agricultural uses as pesticides, herbicides are reported to promote the presence of $\mathrm{As}(\mathrm{V})$ in the environment [6]. A survey reports that about 80 million people in Bangladesh are exposed to contaminated groundwater having concentrations above Bangladesh standard of $50 \mu \mathrm{gL}^{-1}[7,8]$.

Considerable volume of work has been carried out to remove $\mathrm{As}(\mathrm{V})$ from contaminated water. Adsorption is considered to be superior to other traditional methods used for the removal of $\mathrm{As}(\mathrm{V})$ due to its low cost [9], relatively high arsenic removal efficiencies [10, 11], ease of operation and handling [12]. A wide variety of adsorbents have already been studied including activated carbon, fly ash, goethite, zeolites, activated alumina, titanium dioxide, iron hydroxide, zero-valent iron, and cation-exchange resins [13-15]. However, most of these adsorbents are either less effective to remove arsenic or too expensive for use as an adsorbent. It is, therefore, quite pertinent to develop new adsorbents which are cheap, more efficient, and rapid towards arsenic ingestion. Recently hydroxyapatite (HAP) attracts the attention of the researchers as a potential adsorbent for toxic heavy metals due to its large specific area, high thermal and chemical stability, and high ionic exchange capacity [16]. Synthesis of HAP from bio-waste (eggshell) will be a significant step to lower the synthetic cost. As $\mathrm{Cu}$ (II) have strong affinity for arsenate than $\mathrm{Ca}(\mathrm{II})$ [17], it is expected that incorporation of $\mathrm{Cu}$ (II) in HAP will increase the $\mathrm{As}(\mathrm{V})$ removal efficiency of the material.

The work aims at preparing pure and $\mathrm{Cu}(\mathrm{II})$-doped HAPs from a bio-waste, eggshell and thermally treat to optimize the adsorption capacity for efficient removal of arsenic(V) from aqueous system.

\section{Experimental}

\subsection{Materials}

Analar grade chemicals di-ammonium hydrogen phosphate (BDH, England), sodium borohydride (Lancaster, England), potassium iodide (Merck, Germany) and copper nitrate (Merck, Germany) were used without further purification. All the substrate solutions were prepared using distilled de-ionized (DI) water with specific conductivity $1.70 \mu \mathrm{Scm}^{-1}$ at $29.5^{\circ} \mathrm{C}$. Eggshells were used as a calcium precursor to the synthesis of pure and $\mathrm{Cu}(\mathrm{II})$ doped HAP. 


\subsection{Synthesis of pure and $\mathrm{Cu}(\mathrm{II})$-doped HAP using wet chemical method}

For the preparation of $0.95 \mathrm{M}$ calcium precursor solution, $25 \mathrm{~g}$ of eggshell powder was dissolved in $50 \mathrm{~mL}$ of concentrated nitric acid. The mixture was filtered to obtain a clear solution and was transferred to a $250 \mathrm{~mL}$ volumetric flask and DI water was added up to the mark. $0.57 \mathrm{M}$ phosphate precursor solution was prepared by dissolving $18.69 \mathrm{~g}$ of $\left(\mathrm{NH}_{4}\right)_{2} \mathrm{HPO}_{4}$ in a $250 \mathrm{~mL}$ volumetric flask with DI water. The phosphate precursor solution was slowly added to the calcium precursor solution with continuous stirring at room temperature $\left(29 \pm 1{ }^{\circ} \mathrm{C}\right)$ and the $\mathrm{pH}$ of the solution was adjusted to ca. 10 by using aqueous $\mathrm{NH}_{3}$. The $\mathrm{Ca} / \mathrm{P}$ ratio was maintained 1.67. A gelatinous precipitate was formed and the slurry was then kept for $24 \mathrm{~h}$. The precipitate was then filtered and washed with water up to 10 times. Finally, the product was thermally treated at temperatures 110,300 and $600{ }^{\circ} \mathrm{C}$. The calcination temperatures were achieved raising the temperature at the rate of $3^{\circ} \mathrm{Cmin}^{-1}$ with $1 \mathrm{~h}$ soaking time. $\mathrm{Cu}$ (II)-doped HAP (Cu-HAP) was synthesized by adding $\mathrm{Cu}^{2+}$ ion solution to calcium precursor prior to the addition of phosphate precursor in the same process. Different quantity of doping salt was used in the synthesis of $\mathrm{Cu}$ HAP. Fig.1. shows the schematic diagram of the synthesis of pure and $\mathrm{Cu}-\mathrm{HAP}$ from eggshells. Table 1 summarizes the sample history.

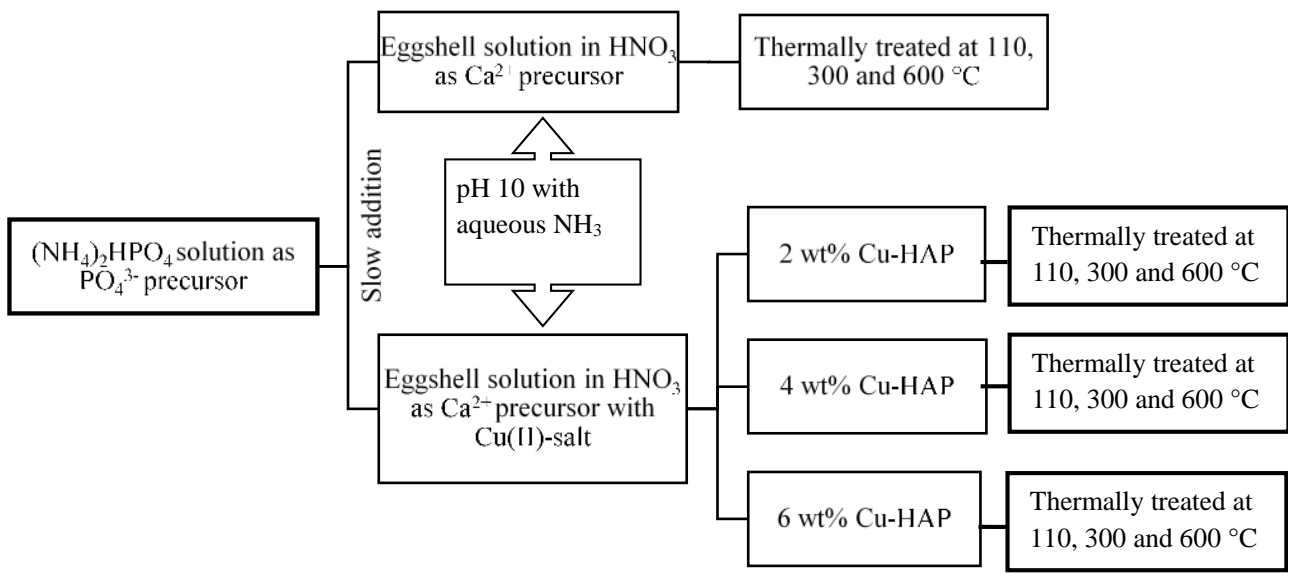

Fig. 1. Schematic diagram for synthesis of pure and $\mathrm{Cu}-\mathrm{HAP}$ from eggshell.

\subsection{Characterization of pure and $\mathrm{Cu}-\mathrm{HAP}$}

Diffractograms of pure and Cu-HAP were recorded by an X-ray diffractometer (PANalytical X'Pert PRO PW 3040) using $\mathrm{CuK}_{\alpha}(\lambda=1.5418 \AA$ ) radiation generated at 40 $\mathrm{kV}$ and $30 \mathrm{~mA}$ within the scan range $2 \theta=5$ to $75^{\circ}$ with a step size $(2 \theta)$ of $0.02^{\circ}$. The phases formed were validated by comparing with the respective standard of Joint Committee on Powder Diffraction (JCPDS) files.

The infrared spectra were recorded in the wavenumber range from 4000 to $400 \mathrm{~cm}^{-1}$ with $4 \mathrm{~cm}^{-1}$ resolution using a Fourier transform infrared (FT-IR) spectrophotometer 
(Prestige21 Shimadzu). A powdered sample (approximately $1 \mathrm{mg}$ ) was mixed with about $100 \mathrm{mg}$ of anhydrous $\mathrm{KBr}$ to prepare the pellet.

Table 1. Sample code of pure and Cu-HAP.

\begin{tabular}{|c|c|c|c|}
\hline Sample & $\begin{array}{l}\mathrm{Wt} \% \\
\mathrm{Cu}\left(\mathrm{NO}_{3}\right)_{2}\end{array}$ & $\begin{array}{l}\text { Calcination } \\
\text { temperature }\left({ }^{\circ} \mathrm{C}\right)\end{array}$ & Sample code \\
\hline \multirow{3}{*}{ Pure HAP } & 0.0 & 110 & HAP1 \\
\hline & & 300 & HAP3 \\
\hline & & 600 & HAP6 \\
\hline \multirow[t]{3}{*}{$2 \% \mathrm{Cu}-\mathrm{HAP}$} & 2.0 & 110 & $2 \% \mathrm{Cu}-\mathrm{HAP} 1$ \\
\hline & & 300 & $2 \% \mathrm{Cu}-\mathrm{HAP} 3$ \\
\hline & & 600 & $2 \% \mathrm{Cu}-\mathrm{HAP} 6$ \\
\hline \multirow[t]{3}{*}{$4 \% \mathrm{Cu}-\mathrm{HAP}$} & 4.0 & 110 & 4\% Cu-HAP1 \\
\hline & & 300 & $4 \% \mathrm{Cu}-\mathrm{HAP} 3$ \\
\hline & & 600 & $4 \% \mathrm{Cu}-\mathrm{HAP} 6$ \\
\hline \multirow[t]{3}{*}{$6 \% \mathrm{Cu}-\mathrm{HAP}$} & 6.0 & 110 & $6 \% \mathrm{Cu}-\mathrm{HAP} 1$ \\
\hline & & 300 & $6 \% \mathrm{Cu}-\mathrm{HAP} 3$ \\
\hline & & 600 & $6 \% \mathrm{Cu}-\mathrm{HAP} 6$ \\
\hline
\end{tabular}

Morphological characterization of the samples was carried out by scanning electron microscopy (SEM) using a Hitachi S-3400 N equipped with energy dispersive spectrophotometer (EDS).

Particle size was measured by dynamic light scattering (DLS) technique using Zetasizer Nano ZS90 (ZEN3690, Malvern Instruments Ltd). A He-Ne laser beam of $632.8 \mathrm{~nm}$ wavelength was used as light source and the measurements were made at a fixed scattering angle of $90^{\circ}$. The scattering intensity data were analyzed to obtain the hydrodynamic diameter $\left(D_{\mathrm{h}}\right)$. Using a cell of $10 \mathrm{~mm}$ diameter, a specific amount of HAP powder was subjected to ultrasonic treatment in aqueous medium for $20 \mathrm{~min}$ which facilitated minimum degree of agglomeration. The particle sizes were determined from the translational diffusion coefficient using the Stokes-Einstein equation [18].

In order to determine surface area, pure and $\mathrm{Cu}-\mathrm{HAP}$ were pretreated by purging $\mathrm{N}_{2}$ gas for $4 \mathrm{~h}$ adjusting heating temperature at $120{ }^{\circ} \mathrm{C}$ to remove moisture and organic impurities from the surface of the particles. Pretreatment of the samples were performed by BELPREP-flowII (BEL Japan, Inc.) and the measurements were carried out by BEL sorp mini II (BEL Japan, Inc.). The adsorption isotherms, generated from $\mathrm{N}_{2}$ gas adsorption-desorption data were used to analyze the pore size distribution, surface area, pore volume, and other properties. The isotherms have different shapes which depend on pore structure of solid as well as interaction between sample surface and adsorbate gas. IUPAC classifications were used to define both adsorption isotherms and adsorption hysteresis loops [19]. Surface area and pore size distribution of adsorbents were calculated from Brunauer, Emmett, and Teller (BET) isotherm [20] and Barrett, Joyner, and Halenda (BJH) plot [21] respectively which were prepared from the data of gas-adsorption measurements.

Hydride generation atomic absorption spectrophotometer (HG-AAS, NOVAA 350, Analytik Jena, Germany) was used to determine concentration of $\mathrm{As}(\mathrm{V})$ in aqueous 
solution. AAS equipped with hydride generation and hollow cathode lamp operated at 10 $\mathrm{mA}$ was used for determination of arsenic(V). A spectral band width of $0.5 \mathrm{~nm}$ was selected to isolate the $193.7 \mathrm{~nm}$ arsenic(As) line. Calibration standards (2, 5, 10 and 20 $\left.\mu \mathrm{gL}^{-1}\right)$ were prepared from the $\mathrm{As}(\mathrm{V})$ stock solution by appropriate dilution of the standard solutions and regression coefficient value $\left(R^{2}\right)$ was $>0.999$. As $(\mathrm{V})$ standards solution was prepared according to the standard procedure (SOP) reported by HG-AAS, NOVAA 350, Analytik Jena, Germany.

\subsection{Removal of arsenic from aqueous system using pure and $\mathrm{Cu}-\mathrm{HAP}$}

Batch experiments were conducted in well capped $150 \mathrm{~mL}$ flasks, containing $50 \mathrm{~mL}$ $\mathrm{As}(\mathrm{V})$ solution with the required concentrations. After the addition of specific amount of adsorbent, the flask was shaken in a thermostatic shaker at $150 \mathrm{rpm}$ and $30^{\circ} \mathrm{C}$ for $60 \mathrm{~min}$. The contents were then centrifuged at $2000 \mathrm{rpm}$ for $15 \mathrm{~min}$ and the supernatant liquid was analyzed for $\mathrm{As}(\mathrm{V})$ ion concentration using hydride generated atomic absorption spectrophotometer (HG-AAS). The effect of $\mathrm{pH}$ in the range of 3.0 to 10.0 was studied with initial arsenic concentration $100 \mu \mathrm{gL}^{-1}$. The effect of adsorbent dosage was studied by varying the adsorbent dosage from 1 to $10 \mathrm{gL}^{-1}$ at $\mathrm{pH}$ 9.0. The initial concentrations of the $\mathrm{As}(\mathrm{V})$ solutions were set from 65 to $170 \mu \mathrm{gL}^{-1}$. The adsorption isotherms were studied at $30^{\circ} \mathrm{C}$, pH 9.0 for $\mathrm{As}(\mathrm{V})$ and were fitted to Langmuir, Freundlich, and Temkin isotherm adsorption models. Samples were collected at different intervals in $100 \mu \mathrm{gL}^{-1}$ of arsenic solution for kinetic study. The $\mathrm{pH}$ values of all the solutions were adjusted by adding $\mathrm{HCl}$ or $\mathrm{NaOH}$ solutions of desired concentrations.

The adsorption capacity of As(V) adsorbed per gram of adsorbent $\left(\mu \mathrm{gg}^{-1}\right)$ and percent of adsorption efficiency were calculated following equations. 1 and 2 [22], respectively.

$$
\begin{aligned}
& q_{e}=\frac{V}{M} \times\left(C_{i}-C_{f}\right) \\
& \text { Adsorption efficiency, } \%=\frac{\left(C_{i}-C_{f}\right)}{C_{i}} \times 100
\end{aligned}
$$

where $C_{i}$ and $C_{\mathrm{f}}$ are the initial and final concentrations of the $\mathrm{As}(\mathrm{V})$ in the aqueous solution in $\mu \mathrm{gL}^{-1}, V$ is the volume of the adsorbate solution in $\mathrm{L}$ and $M$ is the mass of the adsorbents in $\mathrm{g}$ used.

\section{Results and Discussion}

\subsection{Characterization of pure and $\mathrm{Cu}-\mathrm{HAP}$}

\subsubsection{Phase identification by XRD}

Fig. 2 shows the XRD patterns of oven dried pure and $\mathrm{Cu}-\mathrm{HAP}$ as an example. Presence of strong diffraction peaks corresponding to HAP phase at $2 \theta$ position $\sim 31.84^{\circ}$ for $(211)$ 
reflection plane and two peaks at 32.18 and $32.89^{\circ}$ confirms the formation of HAP phase in the samples [23]. XRD data are in good agreement with JCPDS file 09-0432 which correspond to hexagonal HAP. No significant change in peak positions is observed (Fig. 2 ), except the decrease in the intensity of peak for (002) plane with increase of $\mathrm{Cu}$ content in HAP structure. This is the indication of increase in amorphous nature of $\mathrm{Cu}-\mathrm{HAP}$ with increase in $\mathrm{Cu}$ content in the samples. Ionic radius of $\mathrm{Cu}(\mathrm{II})(0.77 \AA)$ is smaller than that of $\mathrm{Ca}$ (II) $(0.99 \AA)$ which induces strain on HAP crystal lattice, thus the crystallinity of the sample is decreased [24].

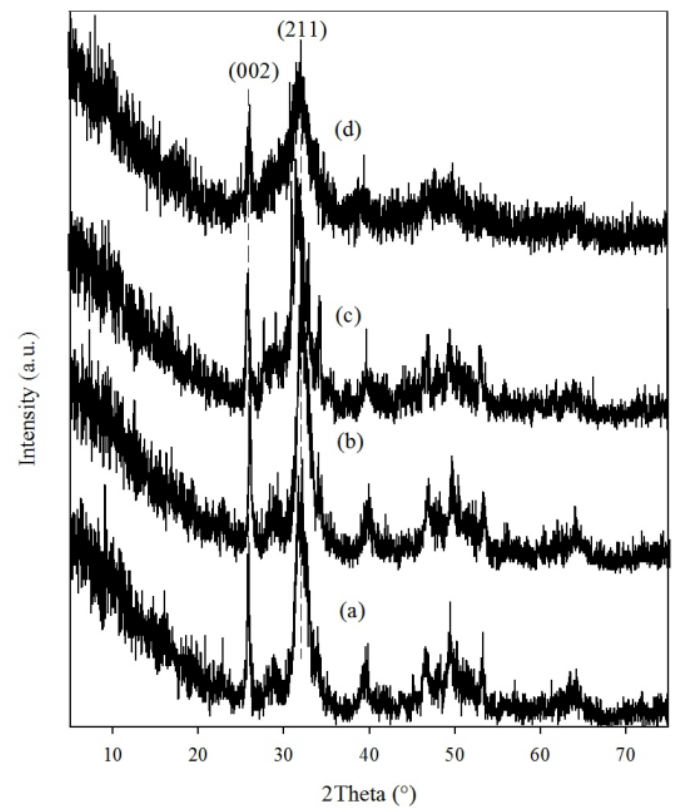

Fig. 2. XRD patterns of synthesized HAP calcined at $110{ }^{\circ} \mathrm{C}$ containing (a) 0 , (b) 2, (c) 4 and (d) 6 wt $\% \mathrm{Cu}$.

XRD pattern of 2\% Cu-HAP6 in Fig. 3 indicates the presence of a second phase along with HAP phase in the sample. XRD pattern shows major peak at $31.27^{\circ}$ in $2 \theta$ for (210) reflection plane along with peak at $2 \theta$ position 34.68 for (220) plane which is almost in equal intensity of the major peak. This pattern is in agreement with JCPDS File $09-0169$ for $\beta$-TCP [25].

Effect of $\mathrm{Cu}$ (II) incorporation in HAP structure was studied by analyzing the crystallographic data. To ensure the formation of desired HAP together with $\beta$-TCP phase, crystallographic information was extensively verified. Crystallite size, lattice parameters $(a, c)$ of HAP and $\beta$-TCP phases were calculated according to the procedures reported by Rezakhani et al. [26] and Kannan et al. [27] and parameters of the samples calcined at 600 ${ }^{\circ} \mathrm{C}$ are presented in Table 2 as an example. 


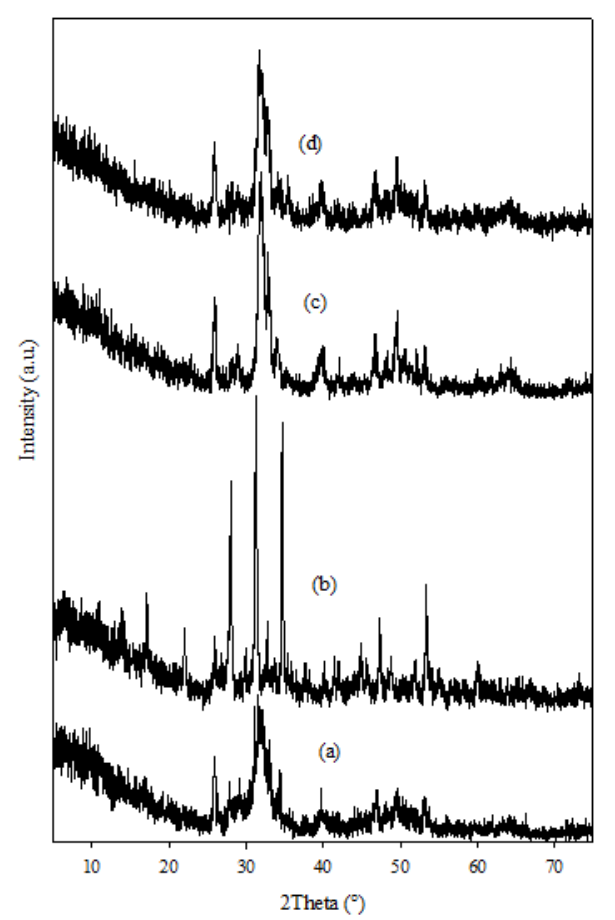

Fig. 3. XRD patterns of synthesized HAP calcined at $600{ }^{\circ} \mathrm{C}$ containing (a) 0 , (b) 2 , (c) 4 , and (d) 6 $\mathrm{wt} \% \mathrm{Cu}$.

Table 2. Calculated and JCPDS crystallographic parameters of Cu-HAP6.

\begin{tabular}{|c|c|c|c|c|}
\hline \multirow[t]{2}{*}{ Sample code } & \multirow[t]{2}{*}{ Phase and symmetry } & \multicolumn{2}{|c|}{$\begin{array}{c}\text { Lattice constants } \\
(\AA)\end{array}$} & \multirow[t]{2}{*}{$\begin{array}{l}\text { Crystallite size } \\
\text { (nm) }\end{array}$} \\
\hline & & $a=b$ & $c$ & \\
\hline $2 \% \mathrm{Cu}-\mathrm{HAP} 6$ & $\begin{array}{c}\beta \text {-TCP } \\
\text { Rhombohedral }\end{array}$ & 10.35 & 37.49 & 78.83 \\
\hline $4 \% \mathrm{Cu}-\mathrm{HAP} 6$ & HAP Hexagonal & 9.43 & 6.88 & 20.35 \\
\hline $6 \% \mathrm{Cu}-\mathrm{HAP} 6$ & HAP Hexagonal & 9.44 & 6.88 & 23.07 \\
\hline JCPDS & HAP & 9.42 & 6.88 & \\
\hline File \# 09-0432 & Hexagonal & & & \\
\hline JCPDS & $\beta-\mathrm{TCP}$ & 10.43 & 37.38 & \\
\hline File \# 09-0169 & Rhombohedral & & & \\
\hline
\end{tabular}

Lattice parameter $c$ (Table 2) is in good agreement with the standard JCPDS value for all Cu-HAP6, while $a$ value is slightly higher than that of standard value. This discrepancy could be due to the amorphous nature of $\mathrm{Cu}-\mathrm{HAP}$. Substitution of larger $\mathrm{Ca}^{2+}$ ion with relatively smaller $\mathrm{Cu}^{2+}$ ion is likely to exert strains in the HAP lattice, which affects the crystallite size at higher $\mathrm{Cu}$ content in $\mathrm{Cu}$-HAP. It is reported that larger ions prefer to substitute $\mathrm{Ca}$ in the Ca-II site for HAP and provokes an increment in lattice parameter $a$ but reduces lattice parameter $c$ [28,29]. However, increase in the cell parameter $a$ with no 
change in the cell parameter $c$ of $4 \%$ and $6 \% \mathrm{Cu}-\mathrm{HAP} 6$ indicates substitution at Ca-II site of the samples.

\subsubsection{Functional group analysis by FT-IR}

Presence of characteristic phosphate and hydroxyl groups in $\mathrm{Cu}-\mathrm{HAP}$ were identified through FT-IR analyses. FT-IR spectra of Cu-HAP6 with different weight percent of $\mathrm{Cu}$ (II) are shown in Fig. 4. The bands at $1090-1030 \mathrm{~cm}^{-1}$ are due to the $v_{3}$ stretching of $\mathrm{PO}_{4}{ }^{3-}$ group, doublet at approximately $601-606 \mathrm{~cm}^{-1}$ and $560-566 \mathrm{~cm}^{-1}$ are due to the $v_{4}$ bending mode of $\mathrm{PO}_{4}{ }^{3-}$ group and very weak bands located at $956-962 \mathrm{~cm}^{-1}$ are attributed to $v_{1}$ stretching mode of $\mathrm{PO}_{4}{ }^{3-}$ present in $\mathrm{Cu}-\mathrm{HAP}$ [30]. The peak at $1627 \mathrm{~cm}^{-1}$ and broad band at approximately $3440 \mathrm{~cm}^{-1}$ correspond to the water adsorbed on the surface of samples. The weak peak at approximately $3537 \mathrm{~cm}^{-1}$ can be ascribed to the stretching vibration mode of the structural $\mathrm{OH}^{-}$group in the lattice. Band appearing at $\sim 2360 \mathrm{~cm}^{-1}$ corresponds to the presence of $\mathrm{CO}_{3}{ }^{2-}$ incorporated from the atmospheric $\mathrm{CO}_{2}$ which was introduced during the wet chemical synthesis of HAP [31]. Incorporation of $\mathrm{CO}_{3}{ }^{2-}$ ions suggests substitution of phosphate in the apatite lattice. Absorption peaks at 870, 1319, 1419 , and $1457 \mathrm{~cm}^{-1}$ indicate $\beta$-type substitution of carbonate group in $\operatorname{HAP}[32,33]$. Stretching vibration for structural $\mathrm{OH}$ group has mostly been masked by the broad $\mathrm{H}_{2} \mathrm{O}$ absorption band and is observed as a shoulder at $3570 \mathrm{~cm}^{-1}$ [34].

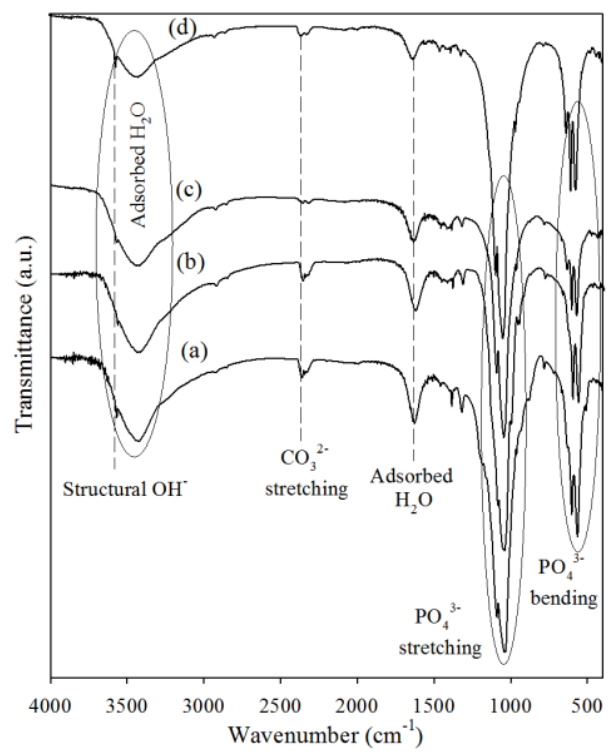

Fig. 4. FT-IR spectra of Cu-HAP from eggshell containing (a) 0, (b) 2, (c) 4 and (d) $6 \mathrm{wt} \% \mathrm{Cu}$.

However characteristic vibration bands for phosphate group in HAP structure remain unchanged in $\mathrm{Cu}-\mathrm{HAP}$. This can be attributed to the fact that thermal treatment of $\mathrm{Cu}$ HAP does not make any change to the HAP phase in the samples. 


\subsubsection{Morphology analysis by SEM}

Fig. 5 shows SEM images of HAP6 with and without $\mathrm{Cu}(\mathrm{II})$. Agglomeration of $\mathrm{Cu}-\mathrm{HAP}$ is noticeable at high concentrations of $\mathrm{Cu}(\mathrm{II})$ in particular at high calcination temperatures. This can be attributed to the fact that increase in calciation temperature as well as the amount of dopant resulted in an amalgamation of the smaller particles of the sample. SEM images (Fig. 5b, 5c) indicate an agglomeration of the particles analyzed with an increase in $\mathrm{Cu}(\mathrm{II})$ content from $2 \mathrm{wt} \%$ to $4 \mathrm{wt} \%$. On the other hand, homogenous distribution is observed in Fig. $5 \mathrm{~b}$ for $2 \% \mathrm{Cu}-\mathrm{HAP} 6$. The particle size of $2 \% \mathrm{Cu}-\mathrm{HAP} 6$ was smaller as compared to pure HAP and $4 \% \mathrm{Cu}-\mathrm{HAP} 6$.

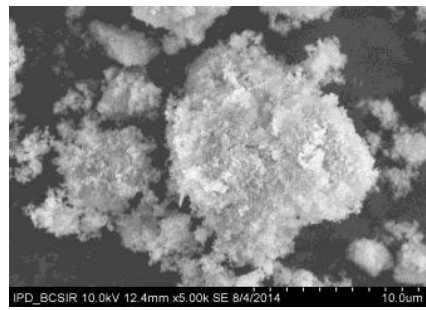

(a)

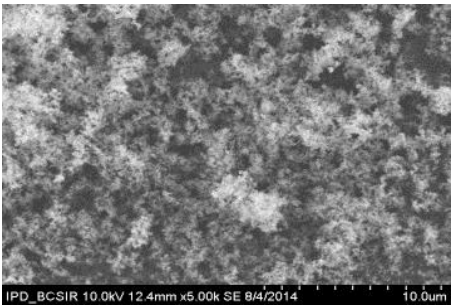

(b)

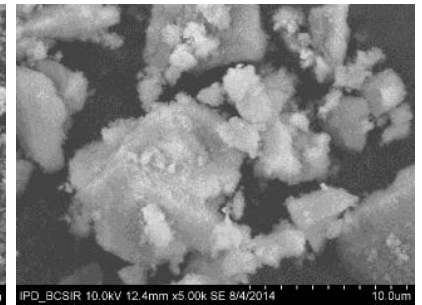

(c)

Fig. 5. SEM images of Cu-HAP6 containing (a) 0, (b) 2 and (c) 4 wt $\% \mathrm{Cu}(\mathrm{II})$.

\subsubsection{Elemental analysis by EDS}

Chemical compositions of all the synthesized samples were determined by EDS analyses. Fig. 6 shows the presence of $\mathrm{Cu}$ along with $\mathrm{Ca}, \mathrm{P}$ and $\mathrm{O}$ with a small amount of carbon in the $\mathrm{Cu}-\mathrm{HAP}$ sample. The $(\mathrm{Ca}+\mathrm{Cu}) / \mathrm{P}$ ratio of the sample is calculated as 1.40 which is less than the expected value of 1.67 for bones. Synthesis of non-stoichiometric $\mathrm{Cu}-\mathrm{HAP}$ may be attributed to the presence of small amount of carbon in the products.

\subsubsection{Analysis of nitrogen adsorption behavior}

Specific surface area and total pore volume were measured using $\mathrm{N}_{2}$ gas (at $77 \mathrm{~K}$ ) adsorption/desorption isotherm. The isotherms for thermally treated $\mathrm{Cu}-\mathrm{HAP}$ both oven dried and calcined at $300{ }^{\circ} \mathrm{C}$ are shown in Fig. 7. Adsorption-desorption isotherm for 2\%Cu-HAP1 (Fig. 7(a)) illustrates type III isotherm with no hysteresis loop. This indicates adsorption on a non-porous surface and surface area of the sample is also very low. Type III isotherm with narrow $\mathrm{H} 1$ hysteresis loop for $2 \% \mathrm{Cu}-\mathrm{HAP} 3$ in Fig. 7(b) indicates the presence of a narrow distribution of relatively uniform cylindrical or tubular pores [35]. 


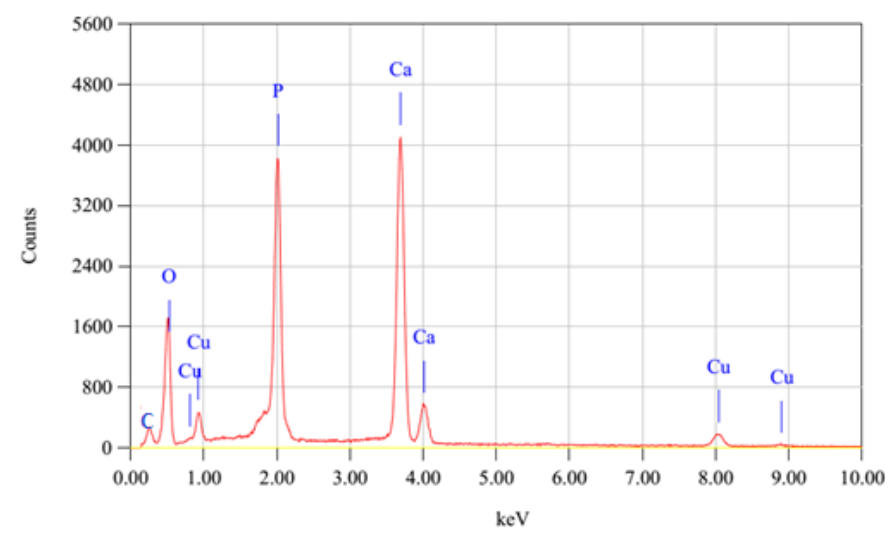

Fig. 6. EDS spectrum of $\mathrm{Cu}-\mathrm{HAP}$ from eggshell.
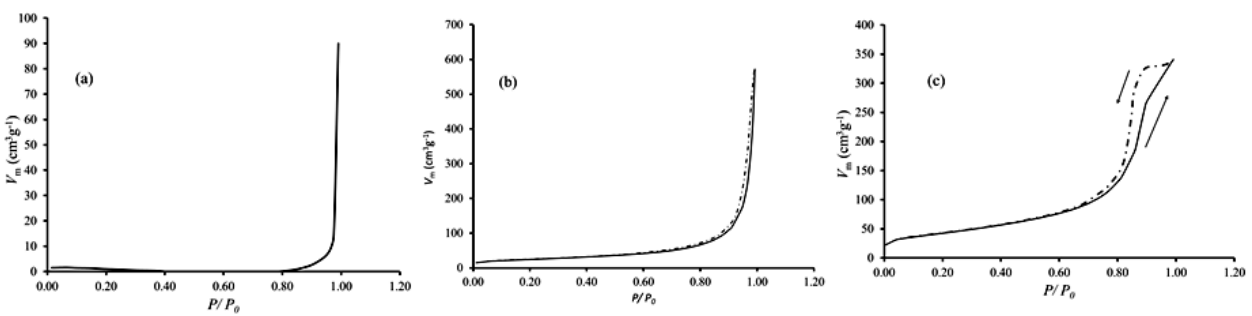

Fig. 7. Adsorption/ desorption isotherm of (a) $2 \% \mathrm{Cu}-\mathrm{HAP} 1$ (b) $2 \% \mathrm{Cu}-\mathrm{HAP} 3$ and (c) $6 \% \mathrm{Cu}-\mathrm{HAP} 3$.

\subsubsection{Analysis of adsorption data by BET isotherm}

Parameters obtained from the analyses of BET plot and BJH plot for $\mathrm{Cu}-\mathrm{HAP}$ are given in Table 3. The lower specific surface area and the pore volumes of $2 \% \mathrm{Cu}-\mathrm{HAP} 1$ is possibly due to the blockage of internal pores by incorporation of $\mathrm{Cu}^{2+}$ ions. Since mean pore diameter of the oven dried sample is larger than calcined $\mathrm{Cu}$-HAP sample, blocked pores are likely to be micropores, resulting in a decrease of specific surface area and total pore volume.

Table 3. Data obtained from analysis of BET isotherms and BJH plot for $\mathrm{Cu}-\mathrm{HAP}$.

\begin{tabular}{llll}
\hline Sample code & $\begin{array}{l}\text { BET surface area, } \\
\left(\mathrm{m}^{2} \mathrm{~g}^{-1}\right)\end{array}$ & $\begin{array}{l}\mathrm{BJH} \text { total pore volume, } \\
\left(\mathrm{cm}^{3} \mathrm{~g}^{1}\right)\end{array}$ & $\begin{array}{l}\text { BJH micropore } \\
\text { diameter, }(\mathrm{nm})\end{array}$ \\
\hline $2 \% \mathrm{Cu}-\mathrm{HAP} 1$ & 6.50 & 0.1311 & 94.44 \\
$2 \% \mathrm{Cu}-\mathrm{HAP3}$ & 86.44 & 0.8803 & 13.90 \\
$6 \% \mathrm{Cu}-\mathrm{HAP} 3$ & 153.39 & 0.5383 & 13.73 \\
\hline
\end{tabular}

BJH plot (Fig. 8a) shows the pore size distribution which indicates the presence of macropores along with mesopores in the sample. Surface area of calcined $\mathrm{Cu}-\mathrm{HAP}$ 
increases with increasing concentration of dopant. However total pore volume decreases with decrease in crystallite size of the samples. Increase in amount of copper in $\mathrm{Cu}-\mathrm{HAP}$ increases specific surface area which indicates incorporation of $\mathrm{Cu}^{2+}$ ions in $\mathrm{Ca}$ sites in HAP matrices. Effect of doping of $\mathrm{Cu}^{2+}$ ion is also consistent with particle size of the samples determined from BET measurements (Table 3).
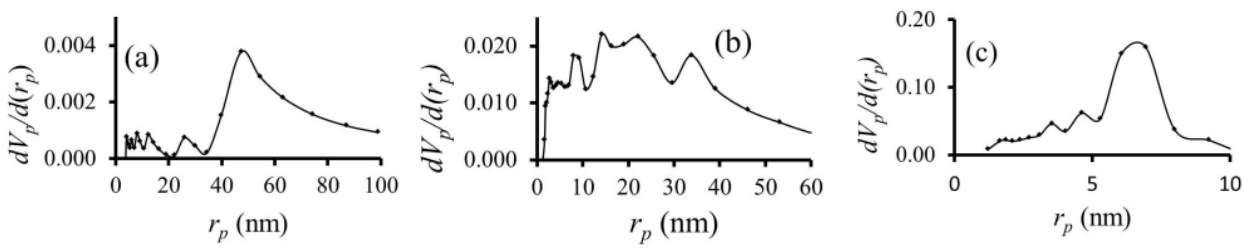

Fig. 8. Differential curves of BJH plot of a $\mathrm{N}_{2}$ adsorption isotherm of (a) $2 \% \mathrm{Cu}-\mathrm{HAP} 1$, (b) $2 \% \mathrm{Cu}-$ HAP3 and (c) $6 \% \mathrm{Cu}-\mathrm{HAP} 3$.

\subsubsection{Particle size and its distribution}

Dynamic light scattering technique was used to determine the particle size distribution (Fig. 9) and average particle size of $\mathrm{Cu}-\mathrm{HAP}$. DLS results show that the average particle size decreases from $2.67 \mu \mathrm{m}$ to $0.47 \mu \mathrm{m}$ when $\mathrm{Cu}(\mathrm{II})$ content increases in the samples from $2 \mathrm{wt} \%$ to $6 \mathrm{wt} \%$. Pure HAP6 has the average particle size of $4.21 \mu \mathrm{m}$ which is higher as compared to HAP doped with $\mathrm{Cu}(\mathrm{II})$. The DLS measurements show correlograms (correlation intensity vs. time; Fig. not shown) with indication of stable species in the system without any sedimentation and aggregation during the course of measurements. In fact, even after prolonged period, no sedimentation or aggregation could be marked.

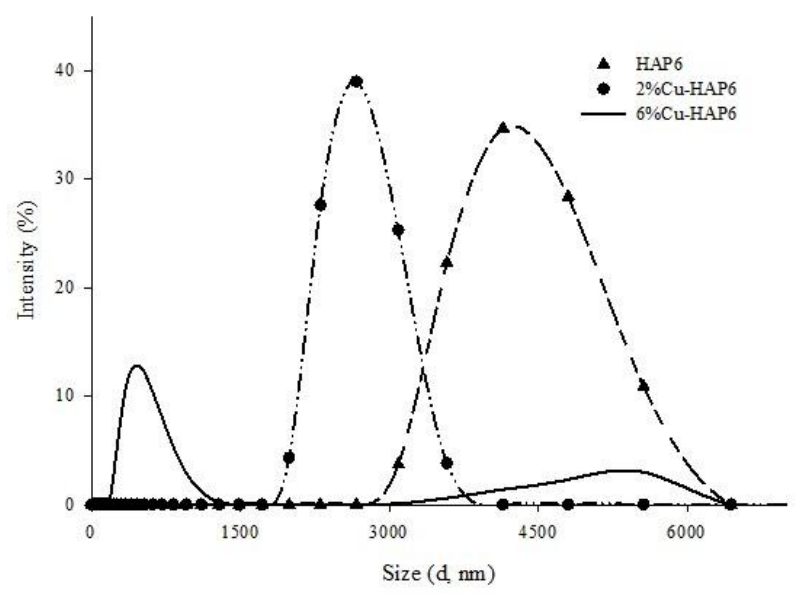

Fig. 9. Particle size distributions of Pure and Cu-HAP. 


\subsection{Adsorption properties}

The optimization of the adsorption parameters was achieved by varying various experimental variables. The optimized adsorption parameters were concentration of arsenate, contact time, $\mathrm{pH}$, and adsorbent dosage.

\subsubsection{Effect of contact time}

Fig. 10 shows the effect of contact time on the percentage removal of $\mathrm{As}(\mathrm{V})$ using pure and $\mathrm{Cu}$-doped $\mathrm{HAP}$ at optimum $\mathrm{pH}$ at $30{ }^{\circ} \mathrm{C}$. Initial $\mathrm{As}(\mathrm{V})$ concentration was $100 \mu \mathrm{gL}^{-1}$. Percentage of As(V) removal efficiency increase with increasing the contact time. Most of adsorption takes place in the initial 20-30 min and then increases slowly and reaches the maximum adsorption in about 50 to 60 min for all adsorbents. Fig. 10 shows that $15.5 \%$ adsorption occurs for thermally treated pure HAP in the first $30 \mathrm{~min}$ and reaches equilibrium at $60 \mathrm{~min}$ with slow increase in efficiency up to $22.5 \%$. Nevertheless initial adsorption efficiency of $\mathrm{Cu}-\mathrm{HAP}$ are in the range of $23-38 \%$ which finally reached at equilibrium with 33-49\%. It is obvious from Fig. 10 that doping of pure HAP increases the adsorption capacity by approximately two fold for $\mathrm{Cu}$ (II) doped products. Rate of removal of $\mathrm{As}(\mathrm{V})$ is higher at the initial stage, due to the availability of more active sites on the surface of pure as well as $\mathrm{Cu}$-HAP. The rate is slower at the later stages probably due to the electrostatic hindrances between negatively charged arsenate species adsorbed on the surface of adsorbents and also due to the reduction of active sites on adsorbents [36]. Slower adsorption rate may also be due to the slower rate of diffusion of arsenate $\mathrm{Cu}-\mathrm{HAP}$ [37].

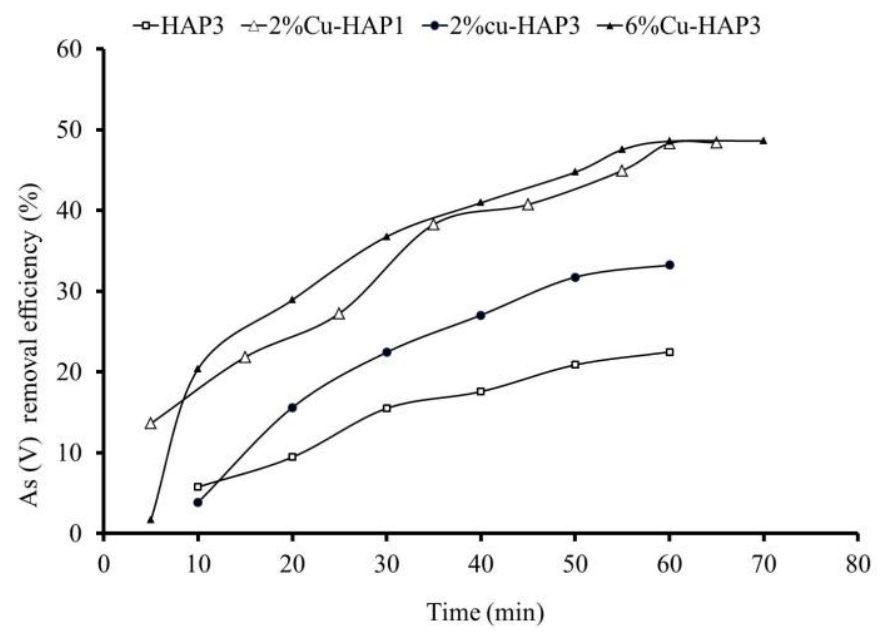

Fig. 10. Effect of contact time on removal of $\mathrm{As}(\mathrm{V})$ by pure and $\mathrm{Cu}-\mathrm{HAP}$. 


\subsubsection{Effect of initial $p H$}

The $\mathrm{pH}$ of the medium influences adsorption and strongly controls the speciation of the arsenic in aqueous system [38]. The type of specific arsenic species available for adsorption is also dependent on the $\mathrm{pH}$ of the medium. The effect of $\mathrm{pH}$ on removal of arsenate on pure and $\mathrm{Cu}-\mathrm{HAP}$ was investigated by varying the solution $\mathrm{pH}$ from 3.0 to 9.0. Temperature was maintained at $30{ }^{\circ} \mathrm{C}$ with contact time $60 \mathrm{~min}$ and initial As(V) concentration was $100 \mu \mathrm{gL}^{-1}$ while adsorbent dosage was maintained $1 \mathrm{gL}^{-1}$. Fig. 11 shows the effects of $\mathrm{pH}$ on adsorption of $\mathrm{As}(\mathrm{V})$ on pure and $\mathrm{Cu}-\mathrm{HAP}$.

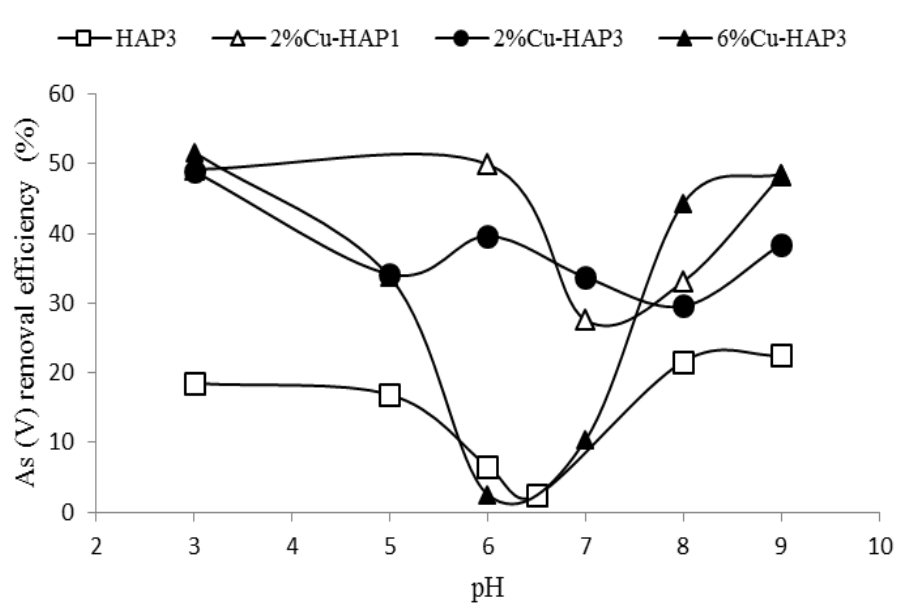

Fig. 11. Effect of $\mathrm{pH}$ on removal of $\mathrm{As}(\mathrm{V})$ using thermally treated pure and $\mathrm{Cu}-\mathrm{HAP}$.

The influence of $\mathrm{pH}$ at $<3.0$ could not be studied since the adsorbents were not stable at $\mathrm{pH}<3.0$. Pourbaix diagram for As species [38] indicates that the stable oxidation state, $\mathrm{As}(\mathrm{V})$ in aqueous system is a monovalent $\left(\mathrm{H}_{2} \mathrm{AsO}_{4}{ }^{-}\right)$anion in the $\mathrm{pH}$ range of 3.0-6.8 or a divalent $\left(\mathrm{HAsO}_{4}{ }^{2-}\right)$ anion in the $\mathrm{pH}$ range of 7.0-11.0. At lower $\mathrm{pH}$, surface of pure and $\mathrm{Cu}-\mathrm{HAP}$ become highly protonated $\left(<\mathrm{pH}_{\mathrm{PZC}}\right)$ which is favorable for removal of $\mathrm{As}(\mathrm{V})$ as the species exists as monovalent anion. For this reason, relatively higher removal efficiency for $\mathrm{As}(\mathrm{V})$ is observed at low $\mathrm{pH}$. Moreover, lowest removal efficiency is observed at $\mathrm{pH}$ 6.0-7.0, which may be attributed to the $\mathrm{pH}_{\mathrm{ZPC}}$ values for $\mathrm{HAP}$ and $\mathrm{Cu}$ HAP (measured $\mathrm{pH}_{\mathrm{ZPC}} 6.5$ and 7.6). A neutral charge condition is developed on surface of the adsorbents at $\mathrm{pH}$ 6.0-7.0. With further increase in $\mathrm{pH}, \mathrm{As}(\mathrm{V})$ removal efficiency increases and reaches a maximum at $\mathrm{pH}$ 9.0. Adsorption of $\mathrm{As}(\mathrm{V})$ anionic species on negatively charged surface $\left(>\mathrm{pH}_{\mathrm{PZC}}\right.$ ) of the adsorbents can thus be easily rationalized. The results thus indicate the exchange of arsenate for phosphate in the HAP structure [39]. 


\subsubsection{Effect of adsorbent dosage}

Fig. 12 shows the effect of dosage variation of pure and $\mathrm{Cu}-\mathrm{HAP}$ on $\mathrm{As}(\mathrm{V})$ removal keeping the other conditions constant. Mass of adsorbent used is an important parameter for the adsorption process since this determines the efficiency of an adsorbent for a given initial concentration of the adsorbate. The equilibrium conditions for studying the adsorption of arsenate are as follows: temperature- $30{ }^{\circ} \mathrm{C}$, contact time- $60 \mathrm{~min}, \mathrm{pH}-9.0$ and initial concentration of arsenate ion- $100 \mu \mathrm{gL}^{-1}$.

Fig. 12 shows adsorption of arsenate on HAP3 decreases from $22.48 \%$ to $18.69 \%$ as adsorbent dosage increases from $1 \mathrm{gL}^{-1}$ to $10 \mathrm{gL}^{-1}$ with a slight increase in the adsorption capacity at HAP3 dosages of 2 and $5 \mathrm{gL}^{-1}$. Adsorption of $\mathrm{As}(\mathrm{V})$ from aqueous media involves exchange of phosphate ion with arsenate ion and concentration of phosphate ion in the solution enhances with increasing exchange of arsenate and phosphate ions. As a consequence, adsorption of arsenate ion on HAP is reduced due to presence of higher phosphate in solution while quantity of HAP increases in the adsorption system [40]. Another reason for reduced adsorption capacity of HAP3 is the lower surface area of the sample which contains less active sites for adsorption. For $6 \% \mathrm{Cu}-\mathrm{HAP} 3$ this capacity enhances from $49 \%$ to $60 \%$ while this increment is not significant in case of $2 \% \mathrm{Cu}-\mathrm{HAP} 1$ and $2 \% \mathrm{Cu}-\mathrm{HAP} 3$. In cases of $\mathrm{Cu}$-doped HAP, specific surface area of the calcined products is higher in comparison to the pure HAP; therefore higher adsorption efficiency is observed due to the availability of active sites on the materials.

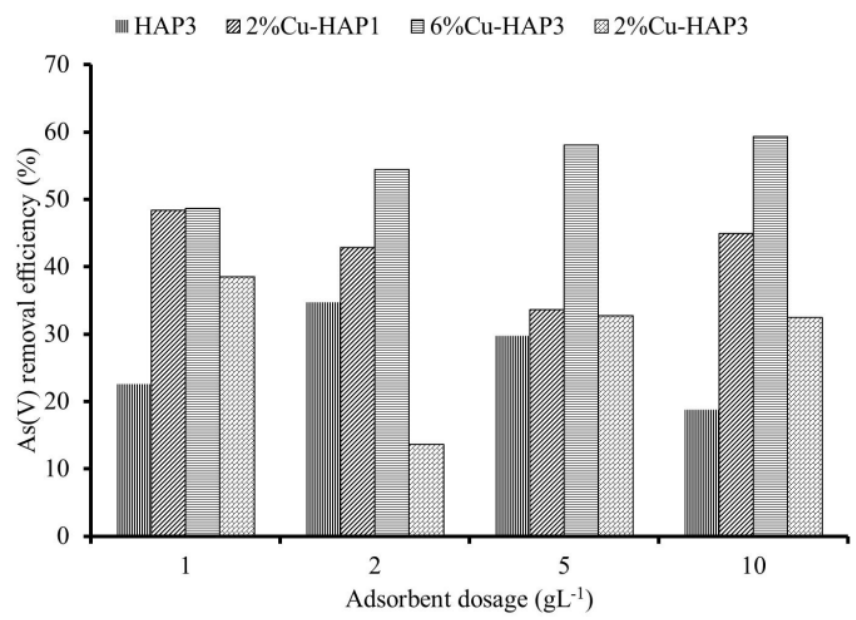

Fig. 12. Effect of adsorbent dosage on removal of $\mathrm{As}(\mathrm{V})$ by pure and $\mathrm{Cu}-\mathrm{HAP}$.

\subsubsection{Effect of initial concentration of $A s(V)$}

Initial concentrations of arsenate ion were varied in the range of $65-170 \mu \mathrm{gL}^{-1}$ and keeping other conditions constant. Fig. 13 reveals that adsorption efficiency is higher at lower initial concentration (50 and $90 \mu \mathrm{gL}^{-1}$ ) and gradually decreases with increase in initial 
arsenic concentration. The reason for the decrease in $\mathrm{As}(\mathrm{V})$ removal efficiency at higher initial concentration may be due to saturation of the active sites of the adsorbent by the $\mathrm{As}(\mathrm{V})$ and hence, further increase in $\mathrm{As}(\mathrm{V})$ concentration does not bring about an increase in adsorption significantly.

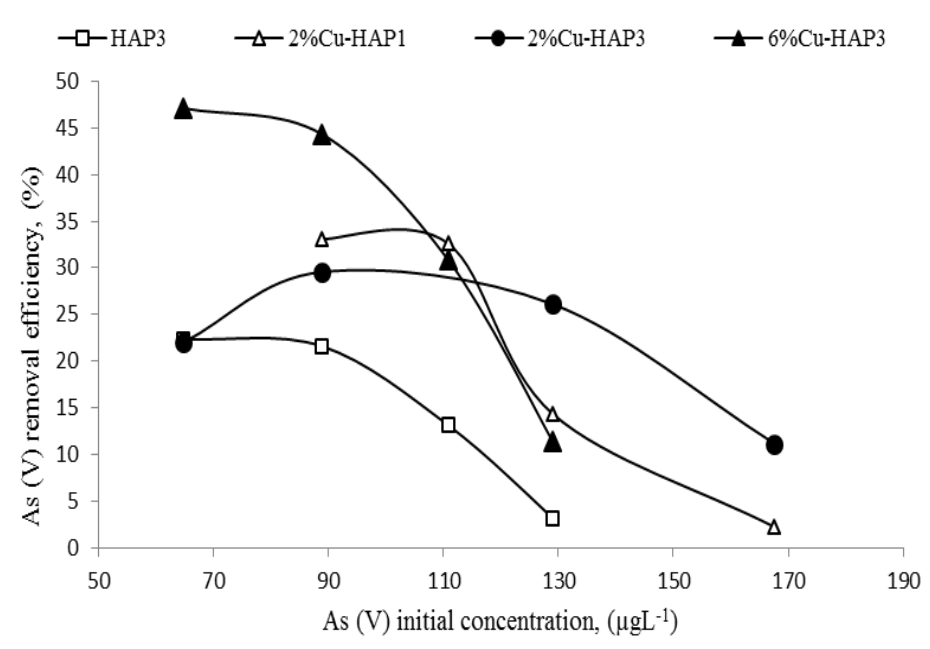

Fig. 13. Effect of initial $\mathrm{As}(\mathrm{V})$ concentration on adsorption on pure and $\mathrm{Cu}-\mathrm{HAP}$.

Fig. 13 shows that arsenate removal efficiency sharply decreased from $22 \%$ to $3 \%$ for pure HAP at varying initial $\mathrm{As}(\mathrm{V})$ concentration. Nevertheless, $\mathrm{Cu}-\mathrm{HAP}$ shows (Fig.13) a sharp decrease in $\mathrm{As}(\mathrm{V})$ removal efficiency with increase in initial $\mathrm{As}(\mathrm{V})$ concentrations as follows: from $47 \%$ to $11 \%$ for $6 \% \mathrm{Cu}-\mathrm{HAP} 3$, from $22 \%$ to $11 \%$ for $2 \% \mathrm{Cu}-\mathrm{HAP} 3$ with an initial slight increase to $29.56 \%$ and from $33 \%$ to $2.21 \%$ for $2 \% \mathrm{Cu}-\mathrm{HAP} 1$. Presence of $\mathrm{Cu}(\mathrm{II})$ in the adsorbents enhances the adsorption efficiency in comparison to pristine HAP [41].

Table 4 compares the adsorption capacity of a series of adsorbents reported in literature for removal of $\mathrm{As}(\mathrm{V})$.

Table 4. Comparison of As(V) adsorption capacity of HAP with other adsorbents.

\begin{tabular}{|c|c|c|c|c|}
\hline $\begin{array}{l}\text { Type of } \\
\text { adsorbent }\end{array}$ & Adsorbents & Adsorption conditions & $\begin{array}{l}\text { Adsorption } \\
\text { capacity }\end{array}$ & Ref. \\
\hline \multirow{6}{*}{ 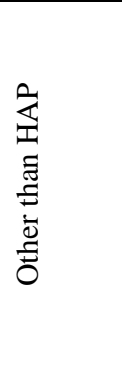 } & Activated alumina & $\begin{array}{l}\text { pH 7.6, adsorbent dosage 1-13 } \\
\mathrm{g} / \mathrm{L}\end{array}$ & $0.18 \mathrm{mg} / \mathrm{g}$ & {$[42]$} \\
\hline & Synthetic zeolite H-MFI-24 & $\mathrm{pH} 6.5$, adsorbent dosage $2 \mathrm{~g} / \mathrm{L}$ & $35.8 \mathrm{mg} / \mathrm{g}$ & [43] \\
\hline & Modified zeoliteY & pH 6 & $1.34 \mathrm{mg} / \mathrm{g}$ & [44] \\
\hline & $\begin{array}{l}\text { Granular ferric hydroxide } \\
(\mathrm{GFH})\end{array}$ & $\begin{array}{l}\mathrm{pH} 6.5 \text {, adsorbent dosage } 0.25 \\
\mathrm{~g} / \mathrm{L}\end{array}$ & $1.1 \mathrm{mg} / \mathrm{g}$ & {$[45]$} \\
\hline & Iron oxide coated sand & $\begin{array}{l}\text { pH 7.5, adsorbent dosage } 20 \\
\text { g/L }\end{array}$ & $\begin{array}{l}0.029 \\
\mathrm{mg} / \mathrm{g}\end{array}$ & [45] \\
\hline & Iron oxide uncoated sand & $\begin{array}{l}\mathrm{pH} 7.5 \text {, adsorbent dosage } 20 \\
\mathrm{~g} / \mathrm{L}\end{array}$ & $0.006 \mathrm{mg} / \mathrm{g}$ & {$[45]$} \\
\hline
\end{tabular}




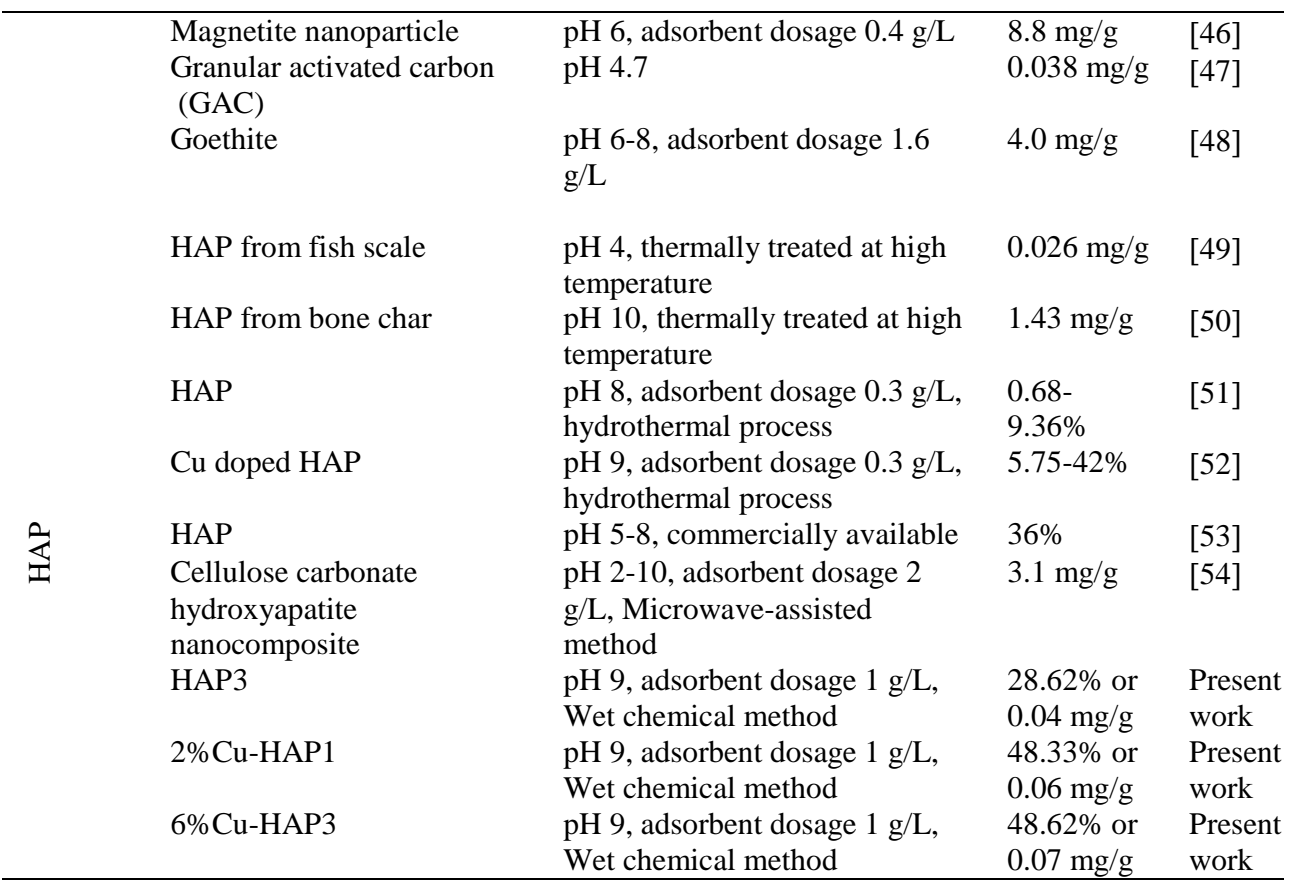

Due to the difference in experimental protocol and synthesis route, an accurate comparison of the removal efficiency is not possible. However, the comparative adsorption capacity has provided the efficiency of $\mathrm{Cu}-\mathrm{HAP}$ used in this work. As(V) removal efficiency of pure and $\mathrm{Cu}-\mathrm{HAP}$ has been compared with other adsorbents. $6 \% \mathrm{Cu}$ HAP3 showed maximum adsorption capacity of $48.62 \%$ equivalent to $0.07 \mathrm{mg} / \mathrm{g}$, which is superior to some commercial adsorbents along with other HAP-based adsorbents. Few adsorbents like synthetic zeolite H-MFI-24, magnetite nanoparticle, cellulose carbonate hydroxyapatite nanocomposite demonstrated better adsorption capacity. Nevertheless the precursor (eggshells) used for synthesis of pure and $\mathrm{Cu}-\mathrm{HAP}$ show the promises of the adsorbent since it may contribute in waste management system. By optimization of the synthesis method and also $\mathrm{Cu}$-content of HAP, potential adsorbents could be prepared to remove $\mathrm{As}(\mathrm{V})$ that can contribute for sustainable development.

\subsection{Adsorption isotherms}

The adsorption isotherm provides information on the capacity of the adsorbent or the amount required for removing a unit mass of pollutant under the operating conditions. In this study, Langmuir, Freundlich, and Temkin adsorption isotherms have been adopted to describe the uptake of $\mathrm{As}(\mathrm{V})$ on pure and $\mathrm{Cu}-\mathrm{HAP}$.

Linear forms of Langmuir, Freundlich, and Temkin isotherm model can be expressed as Eq. (1), (2) and (3) respectively, 


$$
\begin{aligned}
& \frac{C_{e}}{q_{e}}=\frac{1}{k_{L} q_{m}}+\frac{C_{e}}{q_{m}} \\
& \log q_{e}=\log K_{F}+(1 / n) \log C_{e} \\
& q_{e}=B_{l} \ln K_{T}+B_{l} \ln C_{e}
\end{aligned}
$$

Where $q_{e}$ is the adsorption capacity at equilibrium $\left(\mu \mathrm{gg}^{-1}\right), q_{\max }$ is the theoretical maximum adsorption capacity of the adsorbent $\left(\mu \mathrm{gg}^{-1}\right), K_{L}$ is the Langmuir constant $\left(\mathrm{L} \mu \mathrm{g}^{-1}\right)$ and $C_{e}$ is the equilibrium $\mathrm{As}(\mathrm{V})$ concentration in the solution $\left(\mu \mathrm{gL}^{-1}\right), q_{\mathrm{e}}$ is the amount adsorbed per unit mass of adsorbent $\left(\mu \mathrm{gg}^{-1}\right), C_{\mathrm{e}}$ is the equilibrium adsorbate concentration in solution $\left(\mu \mathrm{gL}^{-1}\right), K_{\mathrm{F}}$ and ' $n$ ' are Freundlich constants related to the adsorption capacity and adsorption intensity respectively. $B_{l}=R T / b, T$ is temperature in $K$, $R$ is universal gas constant $\left(8.314 \mathrm{Jmol}^{-1} \mathrm{k}^{-1}\right), K_{T}$ is the equilibrium binding constant $\left(\mathrm{Lmg}^{-}\right.$ ${ }^{1}$ ) and $B_{l}$ is related to the heat of adsorption. The magnitude of $K_{\mathrm{F}}$ and $n$ shows easy separation of heavy metal ion from wastewater and high adsorption capacity. If $n$ lies between 1 and 10, this indicates a favorable adsorption process. Results of Langmuir (Fig.

\begin{tabular}{|c|c|c|c|c|c|c|c|c|c|}
\hline \multirow[b]{2}{*}{$\begin{array}{l}\text { Sample } \\
\text { code }\end{array}$} & \multicolumn{3}{|c|}{ Langmuir adsorption isotherm } & \multicolumn{3}{|c|}{ Freundlich adsorption isotherm } & \multicolumn{3}{|c|}{ Temkin isotherm } \\
\hline & $\begin{array}{l}q_{\mathrm{m}} \\
\mu \mathrm{gg}^{-1}\end{array}$ & $\begin{array}{l}\text { Langmuir } \\
\text { constant, } \\
K_{\mathrm{L}}, \mathrm{L}_{\mu \mathrm{g}^{-1}} \\
\left(\times 10^{-2}\right)\end{array}$ & $R^{2}$ & $\begin{array}{l}\text { Freundlich } \\
\text { constant, } K_{\mathrm{F}}, \\
(\mu \mathrm{g} / \mathrm{g})(\mathrm{L} / \\
\mu \mathrm{g})^{1 / \mathrm{n}}\end{array}$ & $\begin{array}{l}\text { Freundlich } \\
\text { constant, } n\end{array}$ & $R^{2}$ & $B_{1}=R T / b$ & $\begin{array}{l}K_{\mathrm{T}} \\
\left({\left.\mathrm{L} \mu \mathrm{g}^{-1}\right)}\right. \\
\left(\times 10^{-3}\right)\end{array}$ & $R^{2}$ \\
\hline HAP3 & 2.475 & -1.75 & 0.9730 & 18.03 & -0.5827 & 0.8871 & -14.69 & 6.00 & 0.7385 \\
\hline $\begin{array}{l}2 \% \mathrm{Cu}- \\
\text { HAP1 }\end{array}$ & 1.180 & -1.48 & 0.9084 & 591.43 & -0.4054 & 0.9674 & -20.14 & 5.93 & 0.9557 \\
\hline $\begin{array}{l}2 \% \mathrm{Cu}- \\
\mathrm{HAP} 3\end{array}$ & 7.463 & -3.48 & 0.9974 & 85.55 & -2.2416 & 0.9879 & -5.95 & 1.51 & 0.9234 \\
\hline $\begin{array}{l}6 \% \mathrm{Cu}- \\
\mathrm{HAP} 3\end{array}$ & 4.810 & -2.66 & 0.9994 & 3932.78 & -0.7457 & 0.9414 & -18.68 & 6.28 & 0.8432 \\
\hline
\end{tabular}
14a), Freundlich (Fig. 14b) and Temkin (Fig. 14c) isotherms are described in Table 4.

Table 5. Parameters of adsorption isotherms.

The correlation coefficients $\left(R^{2}\right)$ (Table 4) for all the adsorbents are higher than 0.9 and Langmuir constants for pure and $\mathrm{Cu}$-HAP were negative to indicate that the adsorption behavior for $\mathrm{As}(\mathrm{V})$ removal system do not follow the assumption on which the Langmuir model is based on. The negative $n$ (Table 4) for As(V) adsorption indicates unfavorable adsorption. The correlation coefficient $\left(R^{2}\right)$ values for the selected adsorbents are lower for Temkin isotherm model considering the $R^{2}$ values of Langmuir and Freundlich models. Moreover, values of $B_{1}$ (heat of adsorption) are negative for pure and $\mathrm{Cu}-\mathrm{HAP}$ samples which indicates that this model also does not describe the adsorption process well. 


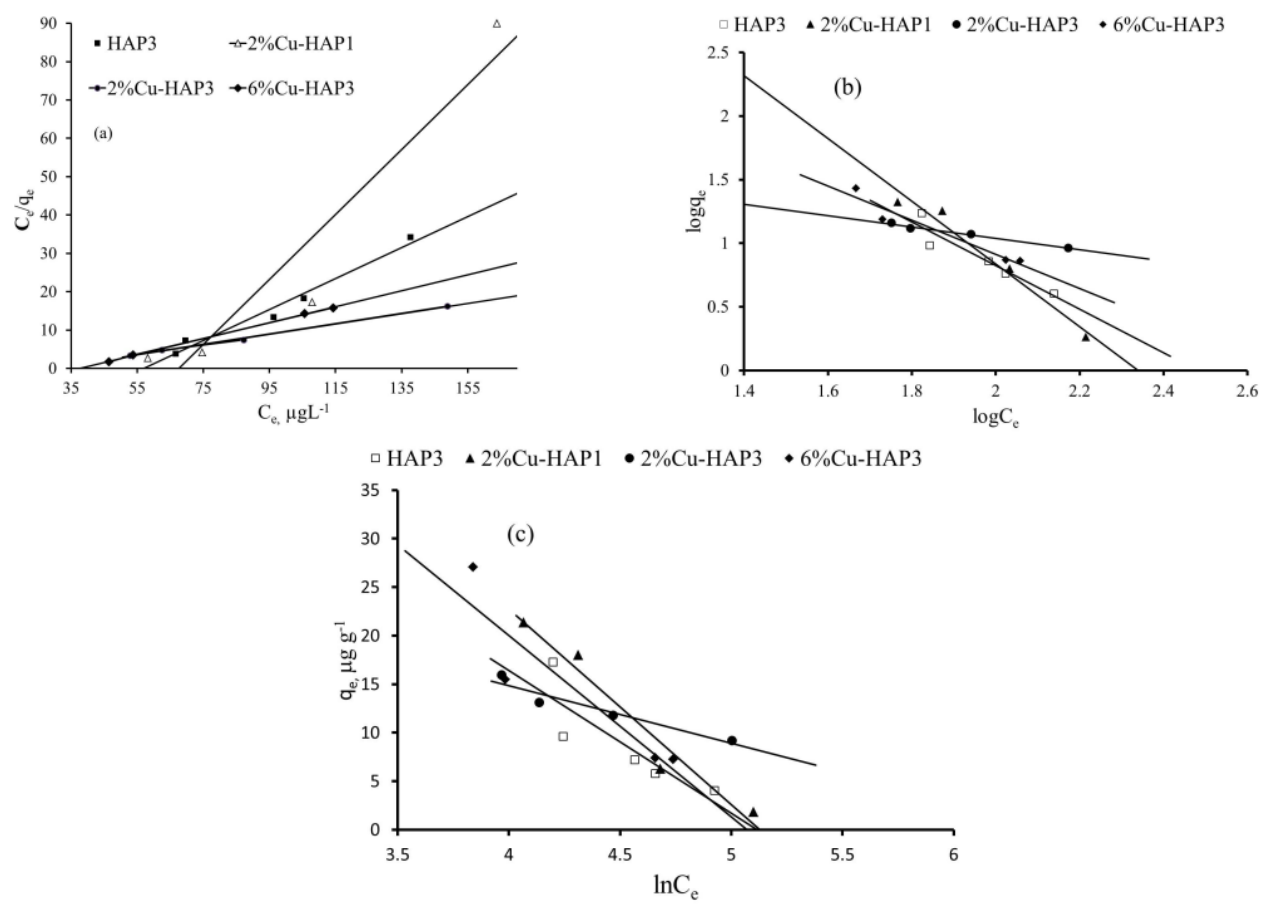

Fig. 14. Adsorption isotherms of (a) Langmuir, (b) Freundlich, and (c) Temkin models for As(V) adsorption on HAP samples.

\section{Conclusions}

Eggshells are excellent, cost-effective, environment friendly, and sustainable calcium precursors of HAP. Pure and Cu-HAP can be successfully synthesized from eggshells by wet chemical precipitation method. Upon calcination at different temperatures in the range of $110-600{ }^{\circ} \mathrm{C}$ they can be employed as adsorbents to remove $\mathrm{As}(\mathrm{V})$ from aqueous system. Incorporation of $\mathrm{Cu}(\mathrm{II})$ in $\mathrm{HAP}$ and thermal treatment at lower temperature facilitates to generate amorphous products with increased specific surface area of the adsorbents. Adsorption studies revealed that equilibrium is established in $60 \mathrm{~min}$ at $\mathrm{pH} 9$ with initial $\mathrm{As}(\mathrm{V})$ concentration $100 \mu^{-1} \mathrm{~L}^{-1}$ at $30{ }^{\circ} \mathrm{C}$. As(V) removal efficiency of HAP increased from $22 \%$ to $48 \%$ as a result of $\mathrm{Cu}$ (II) incorporation. Adsorption data fit well to the Langmuir, Freundlich, and Temkin isotherm models. However, negative values for the calculated parameters implies the inadequacy of the isotherm models to explain the adsorption process.

\section{Acknowledgment}

The authors acknowledge financial support from Higher Education Quality Enhancement Project under the Sub-project, CPSF-231 from Bangladesh University Grants Commission 
financed by World Bank and the Ministry of Education, Bangladesh. SAJ also acknowledges the Ministry of Science and Technology, Bangladesh, for 'Bangabandhu Fellowship'.

\section{References}

1. D. V. Halem, S. Bakker, G. Amy, and J. V. Dijk, Drinking Water Eng. Sci. 2, 29 (2009).

2. T. Budinova, D. Savova, B. Tsyntsarski, C. O. Ania, B. Cabal, J. B. Parra, and N. Petrov, Appl. Surf. Sci. 255, 4650 (2009). https://doi.org/10.1016/j.apsusc.2008.12.013

3. WHO. Arsenic in Drinking Water; Organisation, W. H., Ed.; WHO (Geneva, Switzerland, 2011).

4. R. Singh, S. Singh, P. Parihar, V. Singh, and S. Prasad, Ecotoxicol. Environ. Saf. 112, 247 (2015). https://doi.org/10.1016/j.ecoenv.2014.10.009

5. Guidelines for Canadian Drinking Water Quality: Guideline Technical Document, by FederalProvincial-Territorial Committee on Drinking Water of the Federal-Provincial-Territorial Committee on Health and the Environment Health (Canada Ottawa, Ontario, 2006).

6. K. F. Akter, PhD Thesis, University of South Australia Centre for Environmental Risk Assessment and Remediation Mawson Lakes Campus Mawson Lakes, SA 5095 Australia (2006).

7. Y. Chen, F. Parvez, M. Gamble, T. Islam, A. Ahmed, M. Argos, and H. Ahsan, Toxicol. Appl. Pharmacol. 239, 184 (2009). https://doi.org/10.1016/j.taap.2009.01.010

8. R. Ratnaike, Postgrad. Med. J. 79, 391 (2003). https://doi.org/10.1136/pmj.79.933.391

9. A. Anjum, P. Lokeswari, M. Kaur, and M. Datta, J. Chromatogr. B, 1, 25 (2011).

10. T. Singh and K. Pant, Sep. Purif. Technol. 36, 139 (2004). https://doi.org/10.1016/S1383-5866(03)00209-0

11. D. Mohan and C. U. Pittman, J. Hazard. Mater. 142, 1 (2007). https://doi.org/10.1016/j.jhazmat.2007.01.006

12. M. Jang, W. Chen, and F. Cannon, Environ. Sci. Technol. 42, 3369 (2008). https://doi.org/10.1021/es702318f

13. N. R. Nicomel, K. Leus, K. Folens, P. V. D. Voort, and G. D. Laing, Int. J. Environ. Res. Public Health. 13, 62 (2016). https://doi.org/10.3390/ijerph13010062

14. B. Razzouki, S. E. L. Hajjaji, K. Azzaoui, A. Errich, A. Lamhamdi, M. Berrabah, and L. L. Elansari, J. Mater. Environ. Sci. 6, 144 (2015).

15. K. Sasaki, H. Nakano, W. Wilopo, Y. Miura, and T. Hirajima, Colloids Surf. A Physicochem. Eng. Asp. 347, 8, (2009). https://doi.org/10.1016/j.colsurfa.2008.10.033

16. S. A. Jahan, M. Y. A. Mollah, S. Ahmed, and M. A. B. H. Susan, Material Today Proceedings 4, 5497 (2017). https://doi.org/10.1016/j.matpr.2017.06.005

17. R. Robins - Proc. Impurity Controland Disposal. CIM Annual Meet. (Vancouver, Canada, 1985) pp.1/1-1/26

18. W. Anderson, D. Kozak, V. A. Coleman, A. K. Jämting, and M. Trau, J. Colloid. Interf. Sci. 405, 322 (2013). https://doi.org/10.1016/j.jcis.2013.02.030

19. S. W. Kenneth, R. Sing, and T. Williams, Adsorpt. Sci. Technol. 22, 773 (2004). https://doi.org/10.1260/0263617053499032

20. S. Brunauer, P. H. Emmett, and E. Teller, J. Am. Chem. Soc. 60, 309 (1938). https://doi.org/10.1021/ja01269a023

21. E. P. Barrett, L. G. Joyner, and P. P. Halenda, J. Am. Chem. Soc. 73, 373 (1951). https://doi.org/10.1021/ja01145a126

22. M. H. Ehrampoush, G. Ghanizadeh and M. T. Ghaneian, Iran. J. Environ. Health. Sci. Eng. 8, 101 (2011).

23. S. Ahmed and M. Ahsan, Bang. J. Sci. Ind. Res. 43, 497 (2008).

24. G. Liu, J. W. Talley, C. Na, S. Larson and L. G. Wolfe, Environ. Sci. Technol. 44, 1366 (2010). https://doi.org/10.1021/es1003507 
25. R. S. Pillai and V. M. Sglavo, Ceram. Int. 41, 2512 (2015). https://doi.org/10.1016/j.ceramint.2014.10.073

26. A. Rezakhani and M. M. K. Motlagh, Int. J. Phy. Sci. 7, 2768 (2012).

27. S. Kannan, J. M. Ventura, and J. M. F. Ferreira, Ceram. Int. 33, 637 (2007). https://doi.org/10.1016/j.ceramint.2006.05.016

28. L. W. Schroeder and M. J. Mathew, J. Solid State Chem. 26, 383 (1978). https://doi.org/10.1016/0022-4596(78)90173-1

29. A. Yasukawa, S. Ouchi, K. Kandori, and T. Ishikawa, J. Mater. Chem. 6, 1401 (1996). https://doi.org/10.1039/JM9960601401

30. J. V. Rau, S. N. Cesaro, D. Ferro, S. M. Barinov, and I. V. Fadeeva, J. Biomed. Mater. Res. Part B: Appl. Biomater. 2, 441 (2004). https://doi.org/10.1002/jbm.b.30111

31. D. Luna-Zaragoza, E. T. Romero-Guzman, and L. R. Reyes-Gutierrez, J. Miner. Mater. Charac. Eng. 8, 591 (2009). https://doi.org/10.4236/jmmce.2009.88052

32. C. W. Chen, C. S. Oakes, K. Byrappa, R. E. Riman, K. Brown, K. S. TenHuisen, and V. F. Janas, J. Mater. Chem. 14, 2425 (2004). https://doi.org/10.1039/B401790K

33. P. Regnier, A. C. Lasaga, R. A. Berner, O. H. Han, and K. W. Zilm, Am. Miner. 79, 809 (1994).

34. A. 'Sl'osarczyk, Z. Paszkiewicz, and C. Paluszkiewicz, J. Mol. Struct. 744, 657 (2005).

35. T. Matthias, Chem. Ing. Tech. 82, 1059 (2010). https://doi.org/10.1002/cite.201000064

36. N. Kannan and K. Karrupasamy, Ind. J. Environ. Protect. 18, 683 (1998).

37. U. C. Ghosh and S. Goswami, water SA. 31, 597 (2005).

38. P. L. Smedley and D. G. Kinniburgh, Appl. Geochem. 17, 517 (2002). https://doi.org/10.1016/S0883-2927(02)00018-5

39. P. Mitchell and J. Gen, Microbiol. 11, 73 (1954).

40. A. Violante, M. Pigna and R. Ragusa $-17^{\text {th }}$ WCSS (Thailand, 2002).

41. V. Lenoble, C. Laclautre, V. Deluchat and B. Bollinger, J. Hazard. Mater. B 123, 262 (2005). https://doi.org/10.1016/j.jhazmat.2005.04.005

42. T. Singh and K. Pant, Sep. Purif. Technol. 36, 139 (2004). https://doi.org/10.1016/S1383-5866(03)00209-0

43. P. Chutia, S. Kato, T. Kojima, and S. Satokawa, J. Hazard. Mater. 162, 440 (2009). https://doi.org/10.1016/j.jhazmat.2008.05.061

44. A. M. Yusof and N. A. Malek, J. Hazard. Mater. 162, 1019 (2009). https://doi.org/10.1016/j.jhazmat.2008.05.134

45. V. Gupta, V. Saini, and N. Jain, J. Colloid Interface Sci. 288, 55 (2005). https://doi.org/10.1016/j.jcis.2005.02.054

46. P. Roy, M. Choudhury, and M. Ali, Int. J. Chem. Environ. Eng. 4, 55 (2013).

47. Z. Gu, J. Fang, B. Deng, Environ. Sci. Technol. 39, 3833 (2005). https://doi.org/10.1021/es048179r

48. V. Lenoble, O. Bouras, V. Deluchat, B. Serpaud, and J. Bollinger, J. Colloid Interface Sci. 225, 52 (2002). https://doi.org/10.1006/jcis.2002.8646

49. M. S. Rahaman, A. Basu, and M. R. Islam, Bioresour. Technol. 99, 2815(2008). https://doi.org/10.1016/j.biortech.2007.06.038

50. Y. N. Chen, L. Y. Chai, and Y. D. Shu, J. Hazard. Mater. 160, 168 (2008). https://doi.org/10.1016/j.jhazmat.2008.02.120

51. G. Liu, J. W. Talley, C. Na, S. Larson, and L. G. Wolfe, Environ. Sci. Technol. 44, 1366 (2010). https://doi.org/10.1021/es1003507

52. M. Mirhosseini, E. Biazar, and K. Saeb, Curr. World Environ. 9, 331 (2014). https://doi.org/10.12944/CWE.9.2.13

53. W. E. Alson - Denver Annual Meeting (2002).

54. P. C. Mishra and R. M. Islam Patel, J. Hazard. Mater. 189, 755 (2011). https://doi.org/10.1016/j.jhazmat.2011.03.051 